\title{
Knowledge Management Model for Scientific and Technological Production
}

\author{
Dra. Ana Eugenia Romo-González ${ }^{1}$, \\ Dra. María de los Ángeles Villalobos- Alonso ${ }^{2}$ \\ ${ }^{I}$ Department of Mechatronics, Universidad Tecnológica de Jalisco, Jalisco, México \\ ${ }^{2}$ Department of Technology of the information and communication, Universidad Tecnológica de Jalisco, \\ Jalisco, México
}

\begin{abstract}
This document describes the design of a Knowledge Management Model that focused on research skills development of the human capital that work in companies of high technology sectors. The main objective of the model is re capitalize the knowledge generated in companies belonging to strategic sectors for increasing competitiveness since the scientific and technological production has an impact on international indicators to measure social welfare and economic development of countries. For the model definition two diagnoses were made and there were analyzed by studying the correlations of knowledge management practices and the research skills of the human capital with scientific production underpinned by validating hypotheses using Confirmatory Factor Analysis with structural equations.
\end{abstract}

Keywords - Conceptual design, Knowledge Management Model, High-tech companies

\section{Introduction}

The Organisation for Economic Co-operation and Development [1] established that the Economies of Knowledge are those that "are directly based on the production, distribution and use of knowledge and information" which maintain an investment in sectors classified as high-tech [2][3][4][5].

Analysis of the Economic Commission for Latin America and the Caribbean (CEPAL) [6] considers that the Science, Technology and Innovation (CTI) are the keystones for enhancing socio-economic development of countries, so their management through Knowledge Management Models (KMM) becomes critical in the development of "key competences for research" [7] that contribute to increasing the scientific and technological production in companies and there impact positively on the synthetic indicators internationally standardized.

Therefore, design a Knowledge Management Model for increase skills in investigation of the human capital that works in high-tech companies is the objective of this research.

The initial components of the model are established based on the analysis of diagnosis Axis III.1. Mexico with quality education of the National Development Plan (NDP) 2013-2018 [8] and the review of literature on KMM. The model is adjusted from two quantitative diagnoses, the first one applied in high-tech companies in seven states of Mexico and the second measuring instrument focused on the human capital of these companies.

The model design must answer the central research questions what is the proper structure of knowledge management model for the development of investigative skills of researchers from the high-tech enterprises? What are the key research skills for the technology area that can be derived from indicators of science and technology? What are the components to integrate knowledge management model to achieve the greatest benefits in business? And what kind of links should be established between model components?

To answer the questions two diagnostics were made, the survey and analysis of the information in the diagnostic allowed to strengthen the final model with a structure of eight components and establish the relationships between them making it a dynamic model, also provide an answer to the hypotheses about the correlations that may exist between the practices of knowledge management with cientific and technological production and the correlations between the research skills of the human capital with the products generated collaboratively or individually; we started from the definition of a set of competencies in the area of research to define and align the model.

This paper begins by reviewing the literature based on the research variables and the study subjects. In the section on methodology it present the research design and instruments used for lifting data which are set analysis in results and finally the conclusions are emerge, so in this document presents the KMM adjusted. 


\section{Theoretical Framework}

Knowledge is the intangible component of greater value to the organizations and society since it is focused on achieving its exploitation to maximize development and maintain its progress. Besides being essential to live and relate effectively in society, knowledge contributes to the creation of innovative products and services [9], so its articulation through KMM is considered as a competitive strategy in the companies.

The need to manage the human intellect to achieve results in the industries through individual and collective skills is a management technique that guarantees business success [10]. In this regard, organizations that operate in the high-tech sectors are more sensitive to the dynamic and changing environments resulting from the application of scientific knowledge and research processes and technological development.

It is set as the primary objective of Knowledge Management (KM) the arrangement, orchestration and organization of a business environment that facilitates implement, develop, share, combine and consolidate the knowledge of people [11]; but because organizations are overwhelmed of flow of information and knowledge assets, it is imperative maintain competitiveness by understanding and proper implementation of the KM for coordinate deliberately and systematically the resources and add value to the organization [12].

The importance of managing human intellect as a management technique that ensures the success of a business [13] shows the approach of the institutions on the need for generation and transfer of knowledge in today's society [14] [15] [16] that is focused on the development of intellectual abilities as an intangible resource, directly related to the types of knowledge and how it is produced.

\subsection{The practices and knowledge management.}

The knowledge management practices are defined as a set of techniques, systems and processes dedicated to the creation, storage, transfer and application of knowledge [17]. Four categories are established [18]: the knowledge creation practices, continuous learning practices, knowledge and feedback systems and management skills.

Studies addressing learning organizations [19] [20] [21] linking the variables of organizational learning with competitiveness by focusing on technological capabilities as a strategic element, indicate that the only source of competitive sustainable advantage is the ability to learn faster than competitors. Organizational behavior as a scientific discipline [10] states that positive change can be achieved with competence management where knowledge contributes steadily.

\subsection{Competencias en investigación.}

The study presented in [22] demonstrated that there is no correlation between IQ and success, but are also associated other factors such as personal attributes, skills and motivations; elements of competition in individuals.

It is considered that the professional research competence contributes to a "significant learning of expertise and skills in research" [23], which enable the design and implementation of projects by exploiting research results. These skills not only are based on the teaching of science, but are developed to enhance quality research [24].

The investigative skills are oriented towards understanding, registration, interpretation, analysis, posing problems and their solution by using formal methods of argumentation, writing and synthesis [25]. It is established as necessary the capacity to defend a position or point of view reasoned and logical manner, and the ability to reflect and defend conclusions [26].

The training of professionals with scientific attitude requires "broad academic mastery of theoretical and methodological aspects of research and teaching, that contribute to the solution of problems of national education and society" [27] and it is required collaborative work for the exhibition of ideas, developing questions, academic commentary, proposals, conclusions and evaluation.

The scheme of the skills in the scientific work established in [28] defines the use of technological resources as essential in the investigation, argumentation, innovation and recognition, processing and interpretation of data for the management of the research process. The inquiry process requires the use of case exploratory media, seeking information [29] and the knowledge and use of specialized databases in depth, including effective ability to search in these databases and the ability to read literature from primary and secondary sources of information [26].

Using the concept of training scenarios [30] and focusing on development of investigative skills [31] it is establishes the need for management to teamwork and collaborative learning [32] to generate strategic alliances articulated in networks that enhance the performance.

The cognitive axes addressed in competences, which are derived from its assessment, depend largely on its classification. Related to these competencies are established six domains of assessment [33], they can be summarized as: methodological, technological, information search, teamwork, and oral and written communication in the area of research. 


\section{III. hypothesis}

The relationship between the application of management practices knowledge and scientific and technological production is based on empirical evidence which establishes that the generation of flexible mechanisms for information to give as a final result an effective articulation of actors in research they strengthen the system of Science, Technology and innovation [34] [35] and the "management of intellectual property" [36] and it is where the following structural hypotheses emerge:

SH1: A model of five independent and simple factors called storage systems, shared knowledge spaces, collaborative learning, application of knowledge and scientific and technological production, will adjust the data in the theoretical model.

SH2: There is a significant positive covariance between the storage systems, the shared knowledge spaces, collaborative learning, application of knowledge and scientific and technological production.

The scientific and technological production refers to the number of patents, utility models and intellectual property registered by the companies, so that are set the following confirmatory hypothesis:

CH1.1: The more storage systems, the higher probability to have scientific and technological production in high-tech companies.

CH1.2: The more shared knowledge spaces, the higher probability to have scientific and technological production in high-tech companies.

CH1.3: The more collaborative learning, the higher probability to have scientific and technological production in high-tech companies.

CH1.4: The more application of knowledge, the higher probability to have scientific and technological production in high-tech companies.

On the other hand, it is considered that the professional research competence contributes to a "significant learning of expertise and research skills" [37], which allow the design and implementation of projects that exploit the results of research in exercise of a profession. It is established that the use of key competencies strategically generates the need to manage the skills for the enterprise production integrating technology [38], allowing raise the research structural hypotheses:

SH3: A model of seven independent and simple factors called methodological domain, project management domain, technological domain, information search domain, domain of oral communication, communication domain written in the area of research and scientific and technological production, will adjust the data in the theoretical model.

SH4: There is a significant positive covariance between the methodological domain, project management domain, technological domain, information search domain, domain of oral communication, communication domain written in the area of research and scientific and technological production.

Scientific and technological production of human capital refers to the amounts reported in the last three years of investigations, articles, books and chapters published, technical reports, conference papers, registration of patents and intellectual property, so that are set the following confirmatory hypothesis:

CH2.1: The more methodological domain, the higher probability to have scientific and technological production.

CH2.2: The more project management domain, the higher probability to have scientific and technological production.

CH2.3: The more technological domain, the higher probability to have scientific and technological production.

CH2.4: The more information search domain, the higher probability to have scientific and technological production.

CH2.5: The more domain of oral communication, the higher probability to have scientific and technological production.

CH2.6: The more communication domain written, the higher probability to have scientific and technological production.

The way in which knowledge is managed in the companies establishes its intellectual capital understood as the "set of personal skills, organizational and relational known and measures through a series of generic and specific indicators" [39].

The established hypotheses are validated or refute for each of the sub-variables that make up the production of the scientific and technological enterprises and the production of the human capital, knowledge management practices and research skills.

\section{Methods and Model Specification}

With a focus on technology companies, this research has a quantitative cut as those presented in [40] [41] [42]. Although the above surveys are exploratory and empirical, the nature of this study is of correlational and explanatory scope with no experimental design because it seeks to identify practices for knowledge 
management in research processes from the perspective of scientific and technological production generated in high-tech enterprises.

This work it also aims to identify whether there is a correlation between research skills possessed by the human capital analyzed from the point of view of the evidence of products, understood as "results or identifiable and tangible products" [43], that will adjust the Knowledge Management Model. To conduct the research process it is divided into three phases (Fig. 1)

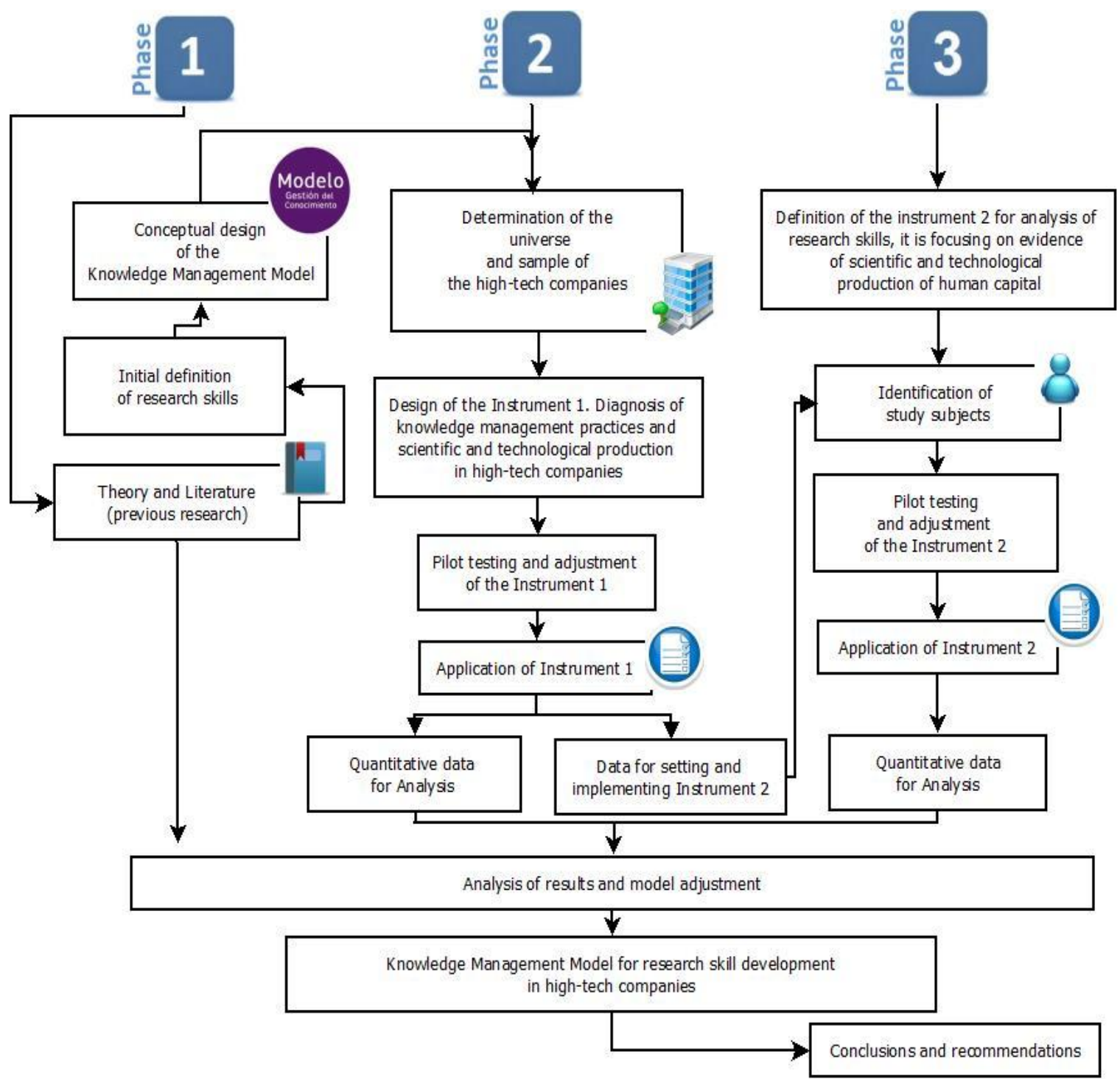

Figure 1. Diagram of the research method. Source: By myself.

Phase 1: The Knowledge Management Model for the development of research skills is conceptually designed.

Phase 2: It is established the population and the sample of the companies that have the characteristics of belong to the sectors Technology of the information and communications, Manufacturing Electronic, Plants for the production of light and heavy vehicles and the Aerospace sector in seven states of the Republic Méxicana (obtaining a total of 112 companies). The research is oriented towards obtaining of the knowledge management practices and the analysis of quantitative data of scientific production through the application of a diagnostic instrument calibrated with a pilot test and its validation in terms of content, construct and criterion.

Phase 3: The application of the previous instrument allows determining the human capital in the research area that have in high-tech companies (giving a total of 190 people). With the information obtained, the second diagnostic instrument is adjusted and is focused on the investigative skills based on individual production.

The statistical data are processed by correlational analysis for the construction of the matrix used as entry in the confirmatory factor analysis using structural equations that allowed adjusting and defining the components of the final conceptual model for knowledge management. 


\section{Results and Discussions}

According to the plan established after obtaining data we proceeded to the verification of the assumptions underlying the model. To test the confirmatory hypothesis two statistical methods were used.

For categorical variables (dichotomous) was used Pearson $r$ and the quantitative variables the Kolmogorov-Smirnov test statistic determined the utilization of Spearman's Rho. In cases where the correlations were negative tests Kaiser-Meyer-Olkin (KMO) and sphericity test Barlett they were made to control the extraction of some factors, which allowed for the Confirmatory Factor Analysis (AFC) framed in structural equation modeling (SEM structural equation models) with IBM AMOS ${ }^{\circledR}$ program in which the Maximum Likelihood procedure [44] was used [45]. They were used as input data "the original scores since their distribution are not normal" [46].

The analysis of scientific and technological production in companies and their relationship to knowledge management practices was conducted in two phases:

In the first phase, the correlations of the variables dichotomous were checked using Pearson's $r$ (equivalent to statistic Phi and $V$ of Cramer, with Ji-square for dichotomous variables and arrays $2 \times 2$ ). They were integrated by counting patent registration, utility models and intellectual property in a categorical variable. The association of the correlation is considered strong if $|\mathrm{r}|>0,70$; moderate if $0,30<=|\mathrm{r}|<=0,70$ and weak if $|\mathrm{r}|<0,3$.

The second phase focuses on the hypothesis test for quantitative variables based on an analysis of verification of normal distribution with the Kolmogorov-Smirnov test. The asymptotic significance (p) showed values below 5\% which shows that the variables do not have a normal distribution so that the correlation for quantitative variables is based on non-parametric statistical analysis through Spearman's Rho. The correlations are summarized in Table 1.

Table 1. Correlations for the variables of knowledge management practices with scientific and technological production in companies

\begin{tabular}{|l|l|l|l|}
\hline Sub-variables & Summary of component & $\begin{array}{l}\text { Degree } \\
\text { correlation }(\boldsymbol{r})\end{array}$ & Hypothesis $(\boldsymbol{p})$ \\
\hline Storage systems & $\begin{array}{l}\text { Database and physical or electronic } \\
\text { files to store information for } \\
\text { research projects, development and } \\
\text { innovation. }\end{array}$ & $\begin{array}{l}r=0,402 \\
\text { Moderate }\end{array}$ & $\begin{array}{l}p=0,000 \text { the null hypothesis is refuted in CH1.1 } \\
\text { then: The more storage systems, the higher } \\
\text { probability to have scientific and technological } \\
\text { production in high-tech companies. }\end{array}$ \\
\hline $\begin{array}{l}\text { Shared } \\
\text { knowledge } \\
\text { spaces }\end{array}$ & $\begin{array}{l}\text { Physical or virtual spaces for } \\
\text { meetings, share experiences and } \\
\text { uptake of ideas; as well as } \\
\text { mechanisms to encourage human } \\
\text { capital to share knowledge. }\end{array}$ & $\begin{array}{l}\text { Moderate } \\
\text { then: The more shared knowledge spaces, the } \\
\text { probability to have scientific and } \\
\text { knowledge, the media, the operating } \\
\text { manuals and technical reports. }\end{array}$ & $\begin{array}{l}\text { Moderate } \\
\text { technological production in high-tech companies. }\end{array}$ \\
\hline $\begin{array}{l}\text { Collaborative } \\
\text { learning }\end{array}$ & $\begin{array}{l}\text { New, completed and generated } \\
\text { projects in the area of research and } \\
\text { development, and services and } \\
\text { processes generated. }\end{array}$ & $\begin{array}{l}r=0,620 \\
\text { Moderate }\end{array}$ & $\begin{array}{l}p=0,016 \text { the null hypothesis is refuted in CH1.3 } \\
\text { then: The more collaborative learning, the higher } \\
\text { probability to have scientific and technological } \\
\text { production in high-tech companies. }\end{array}$ \\
\hline $\begin{array}{l}\text { Application } \\
\text { knowledge }\end{array}$ & $\begin{array}{l}p=0,000 \text { the null hypothesis is refuted in CH1.4 } \\
\text { then: The more application of knowledge, the } \\
\text { higher probability to have scientific and } \\
\text { and } \\
\text { technological production in high-tech companies. }\end{array}$ \\
\hline
\end{tabular}

Statistical analysis showed that all correlations between knowledge management practices and scientific and technological production in high-tech companies have a positive sense. However, in the case of the sub-variable named "shared knowledge spaces", the correlation factor for PIA2P3 was $r=, 095$ with a value of significance of $p=0,320$ and in the sub-variable named "application of knowledge" the values for the factor PIA2P14 were $r=0,095 p=0,839$ so the physical spaces for meetings or share experiences and the quantity of services produced showed no correlation with patents, utility models and intellectual property, so the above factors were extracted for the final fit of the model (Fig. 2). 


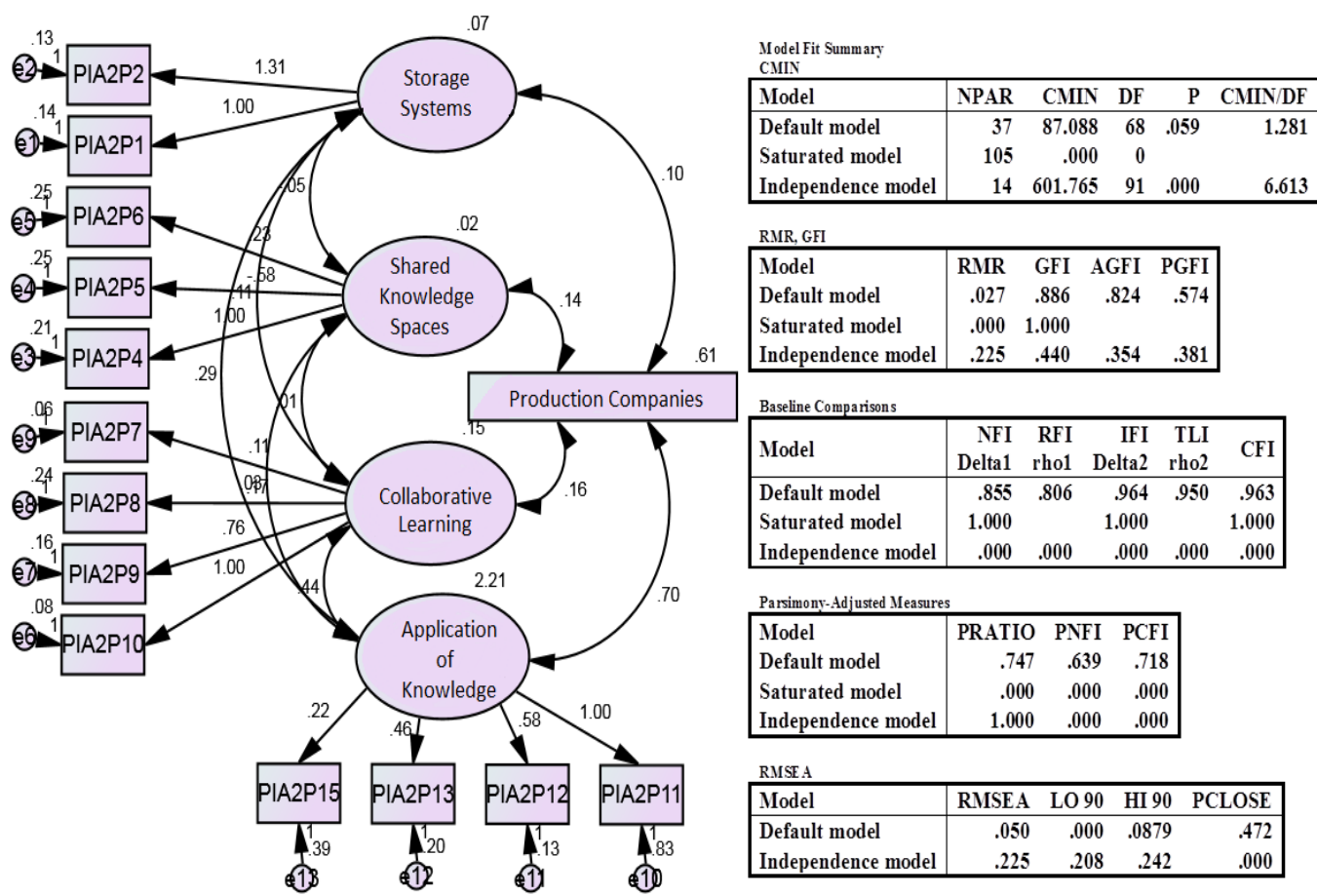

Figure 2. Confirmatory Factor Analysis to adjust the Model of knowledge management practices and the science and technology production in companies.

In Confirmatory Factor Analysis (CFA) that is shown in Fig. 2, is observed that the positive correlations between the sub-variables of management knowledge practices and scientific production enterprises remain after extraction of the factors (PIA2P3) and (PIA2P14).

\section{Validity of the structural hypothesis: SH1.}

The validity of the general estructual SH1 hypothesis is based on obtaining Ji square values for $X^{2}=$ 87,08 with $d f=68$ thats gives a general value adjustment model of $p=0,059$, which is greater than 0,05 , confirming that a model of five factors, independents and simples, called storage systems, shared knowledge spaces, collaborative learning, application of knowledge and scientific and technological production, adjusted the data of the theoretical model.

\section{Validity of the structural hypothesis: SH2.}

It is important condierar other indices of goodness of fit to determine if the condition of rapprochement between data matrices is held ,as the Incremental Adjustment Index which was higher than 0,90 (IFI) = 0,964 with the Root Mean Square Error of Approximation (RMSEA) = 0,050, which according to [47] indicates a superior fit in the model which validates the structural hypothesis $\mathrm{SH} 2$, since there is a significant covariate positive between storage systems, spaces shared knowledge, collaborative learning, application of knowledge and scientific and technological production.

After analyzing the variable of knowledge management practices, is presented the results obtained on scientific and technological production of the human capital and the research skills. Since knowledge of individuals is an intangible asset in business, the hypothesis SH3 established at the beginning of the investigation is linked to the scientific and technological production of human capital and research skills that they have.

The analysis begins by checking the normal distribution with the Kolmogorov-Smirnov test of variables of the scientific and technological production of human capital in the last three years (PIIA1P5: Investigations, PIIA1P6: Articles, PIIA1P7: Books, PIIA1P8: chapters PIIA1P9: Technical Reports, PIIA1P10: Papers, PIIA1P11: Patents, PIIA1P12: Intellectual Property).

It was found that the asymptotic significance (p) showed values below 5\% demonstrating that the variables do not have a normal distribution so that the correlation is based on nonparametric statistics through Spearman's Rho.

The summary of the analysis and degree of correlations with their interpretation is presented in Table 2 for all components of the variable in research skills with variable scientific and technological production of human capital. 
Tabla 2. Correlations for the variables of research skills with scientific and the technological production of the human capital

\begin{tabular}{|c|c|c|c|}
\hline Sub-variables & Summary of component & $\begin{array}{l}\text { Degree of } \\
\text { correlation }(r)\end{array}$ & Hypothesis (p) \\
\hline $\begin{array}{l}\text { Project } \\
\text { management } \\
\text { domain }\end{array}$ & $\begin{array}{l}\text { Comprised of performance as project } \\
\text { leader, the development of resource } \\
\text { plans, types of financing and } \\
\text { collaborative networks in which it } \\
\text { participates. }\end{array}$ & $\begin{array}{l}r=0,613 \\
\text { Moderate }\end{array}$ & $\begin{array}{l}p=0,000 \text { the null hypothesis is refuted in CH2.2 } \\
\text { then: The more project management domain, the } \\
\text { higher probability to have scientific and } \\
\text { technological production. }\end{array}$ \\
\hline $\begin{array}{l}\text { Technological } \\
\text { domain }\end{array}$ & $\begin{array}{l}\text { Composed by the access to knowledge } \\
\text { databases, statistical packages used } \\
\text { and use of software for graphics } \\
\text { design and databases to store and } \\
\text { retrieve projects. }\end{array}$ & $\begin{array}{l}r=0,519 \\
\text { Moderate }\end{array}$ & $\begin{array}{l}p=0,000 \text { the null hypothesis is refuted in } \mathbf{C H 2 . 3} \\
\text { then: The more technological domain, the higher } \\
\text { probability to have scientific and technological } \\
\text { production. }\end{array}$ \\
\hline $\begin{array}{l}\text { Domain of oral } \\
\text { communication }\end{array}$ & $\begin{array}{l}\text { It integrates the types of papers } \\
\text { presented at conferences, workshops } \\
\text { and seminars. }\end{array}$ & $\begin{array}{l}r=0,253 \\
\text { Weak }\end{array}$ & $\begin{array}{l}p=0,005 \text { the null hypothesis is refuted in CH2.5 } \\
\text { then: The more domain of oral communication, } \\
\text { the higher probability to have scientific and } \\
\text { technological production. }\end{array}$ \\
\hline $\begin{array}{l}\text { Communication } \\
\text { domain written }\end{array}$ & $\begin{array}{l}\text { It is comprised of the publication of } \\
\text { indexed articles, information and } \\
\text { dissemination articles, references in } \\
\text { articles, results in congresses, } \\
\text { authoring books and references of } \\
\text { books. }\end{array}$ & $\begin{array}{l}r=0,191 \\
\text { Weak }\end{array}$ & $\begin{array}{l}\mathrm{p}=0,004 \text { the null hypothesis is refuted in CH2.6 } \\
\text { then: The more communication domain written, } \\
\text { the higher probability to have scientific and } \\
\text { technological production. }\end{array}$ \\
\hline
\end{tabular}

Statistical analysis showed that all correlations between the comptetences in research and scientific and technological production of human capital that works in HT companies have a positive sense and values of $p$ $<0.05$ that allow refute the null hypotheses.

However, in the domains of oral and written communication, the degrees of correlation are weak and they have a direct negative impact on international bibliometric indicator and the citation index. These domains also have a link with the methodological domain, whose degree of correlation was weak. Lack of methodological skills, in terms of specifying the type of research, decreases the chances of generating production. These factors were extracted for final adjustment of the model (Fig. 3).
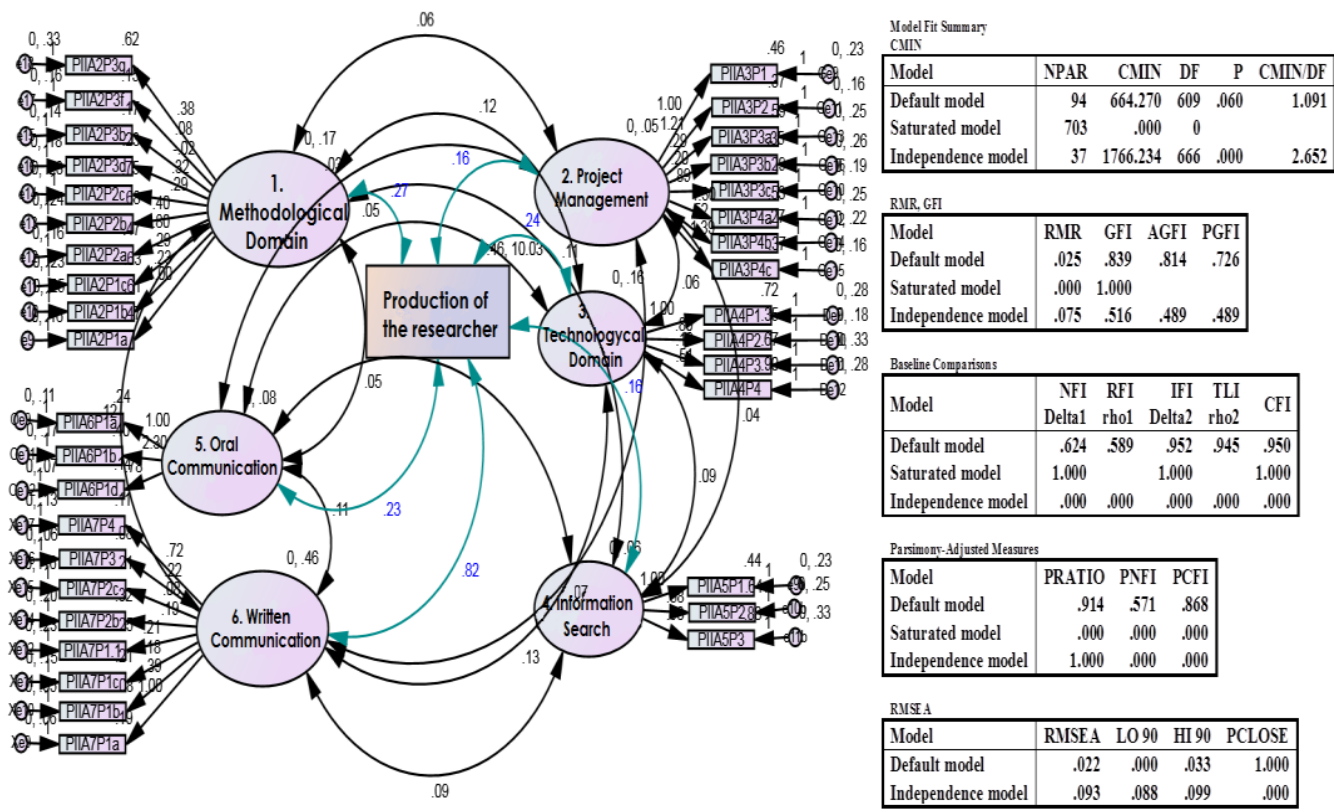

Figure 3. Confirmatory Factor Analysis to adjust the Model of knowledge management of competences in research of human capital and their science and technology production. 


\section{Validity of the structural hypothesis: SH3.}

The validity of the general estructual SH3 hypothesis is based on obtaining Ji square values for $X^{2}=$ 664,270 , with $g l=609$ (Fig. 3) thats gives a general value adjustment model of $p=0,060$, which is greater than 0,05 , confirming that a model of seven factors, independents and simples, called methodological domain, project management domain, technological domain, information search domain, domain of oral communication, communication domain written in the area of research and scientific and technological production, adjusted the data of the theoretical model.

\section{Validity of the structural hypothesis: SH4.}

Because the Incremental Adjustment Index was higher than 0,90 (IFI) = 0,964 with the Root Mean Square Error of Approximation (RMSEA) $=0,022$ which indicates a superior fit in the model, which indicates a superior fit in the model, the structural hypothesis SH4 is validates, since there is a significant covariate positive between methodological domain, project management domain, technological domain, information search domain, domain of oral communication, communication domain written in the area of research and scientific and technological production.

\section{Defining the structure of Knowledge Management Model.}

The statistical information allowed establishing the necessary components for the definition and operation of KMM, the components are set from the validation of structural hypothesis; the four components for knowledge management practices are integrated. The set of skills in the research area are defined based on the correlations of the six verified domains.

During the implementation process model, techniques were used knowledge management to develop projects of high implemented impact. For the implementation of projects collaborative teams were formed, the knowledge generated must be stored as part of intellectual and relational capital of the organization with the aim of strengthening scientific and technological production

The diffusion and dissemination of production, both internally and externally, is carried out in adherence to policies and objectives organizational for the research area. It is important to guaranty the intellectual and industrial property that leads to analysis the skills and the subsequent transfer or assimilation of the technology according to the performance of individuals and collective learning.

It is intended that the process described below, will maintain constantly updated the set of research skills necessary for the development of projects in high technology companies and provide a competitive advantage.

The model is built according of the management policies, the development programs and the research objectives of high-tech companies. The realationship area in conjunction with Management and the Department of research must be related to external entities [48], to promote the generation of ideas and innovation processes in order to establish the database of projects, access to funds and the necessary skills to develop human capital that is working in enterprises [49] [38]. The resulting structure of model components and their relationships are shown in Fig. 4.

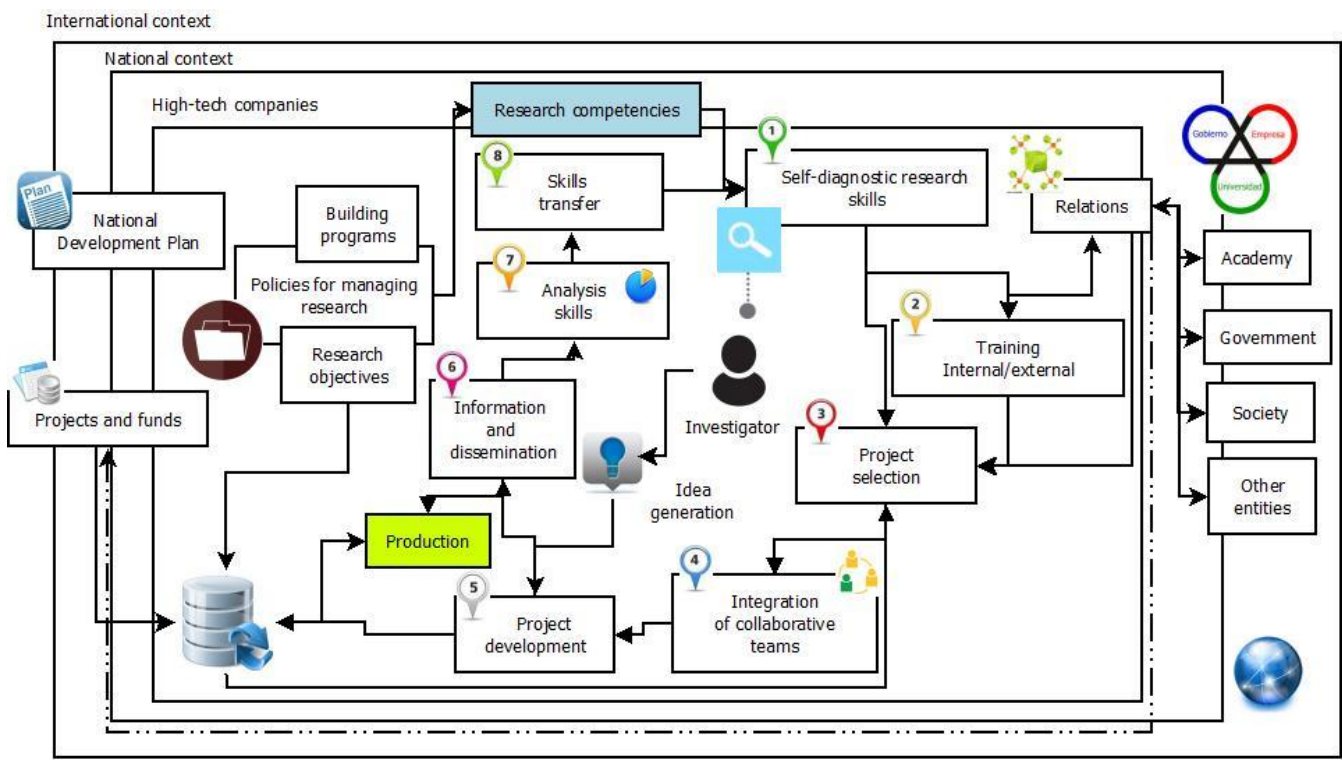

Figure 4. Knowledge Management Model for the development of research skills and promotion of scientific and technological production in high-tech companies. Source: Made by myself 
The learning cycle Figure 4 focuses on the researcher and the process follow eight linear states:

1) Self-diagnosis: The purpose of self-assessment is that it allows individuals to "identify and recognize their own power and ability to face the world of the organization" [50]. In the learning model described the selfdiagnosis of competencies helps to establish the level of human capital skills through instruments of measure and diagnosis [51].

2) Need for training or education: The definitions of training needs or training are established from selfdiagnosis, which are in function to the necessary skills to develop in the company. The training is defined from the perspective of dynamic systematization for the generation and accumulation of knowledge using technology [52].

3) Selection of projects: The efective process of linking businesses allow to select optimally high-impact projects through programs to strengthen the high-tech companies [53] therefore, the selection of projects is essential for the competitiveness of the company and should not be based only on the skills of the investigator.

4) Integration in collaborative teams: The integration of teams and management for collaborative work should generate strategic alliances between research groups, these groups must be articulate in networks for enhancing the performance [32] [31] although their integration depends on the type of project and the competences of the researchers, the flow of knowledge between internal and external members promotes better results of innovation [18].

5) Development of projects: The methodology for the development of projects is determined by its type and scope of the research in accordance with the policies and standards of business quality that each high-tech sector have. However, the scheme of research skill proposed can establish relationships between scientific work [28] for processing and management the interpretation of data made during the research process.

6) Dissemination and divulgation: The production generated is part of the indicators for activity named "products or results" [54] [55], as patents applied for and granted [56] [57] as well as the number of publications and their references in databases; so they should be part of the intangible assets of the company and be available for internal and external divulgation.

7) Analysis of skills: It is important to determine and store the type of developed skills that can be evaluated by measuring the depth of learning in the organization [58]. The evaluation and measurement [59] sets the performance of individuals and skills developed in the organization. Refers to the ability of companies to create value in the future [60] [61] [62] in terms of productivity and innovation [63].

8) Transfer of skills: To consolidate knowledge in the organization in addition to its disposal, application and development is necessary to share it in an organized and systematic manner [64], the transfer of personal skills during the project management contributes to collective learning in the company [65], is important transforming individual knowledge [66] [67] [68] [69] to recapitalize it and avoid waste [70] [71].

The design of the organizational structure in line with the business strategy, should allow the development of knowledge through the use of models for management considering the abilities in research that has the human capital. So the proposed model contributes to the strengthening of the human capital, and the structural and relational capital sustained by the theoretical framework proposed. According to the validation of research hypothesis, the model has a database to store and retrieve research projects including electronic files; and virtual spaces to capture ideas that foster innovation and become new products or process improvement.

The application of the Knowledge Management Model for the development of research skills in hightech companies represents an opportunity to promote research. Its design is based on the theoretical point of view in the literature review and statistical analysis, the ease of model application is oriented towards obtaining results in the short term.

\section{References}

[1] Organisation for Economic Co-operation and Development, The knowledge-based economy. OECD/GD(96)102. París 1996. Recovered from: www.oecd.org/sti/sci-tech/1913021.pdf: 1996.

[2] National Classification of Economic Activities. CNAE-93. Sectores de alta tecnología. Retrieved from: www.cnae.com.es: 2009

[3] Statistical Office of the European Communities. NACE Rev. 2 - Statistical classification of economic activities. Eurostat. Retrieved from: http://epp.eurostat.ec.europa.eu/portal/page/portal/nace_rev2/introduction: 2011

[4] Organisation for Economic Co-operation and Development, Science, Technology and Industry Scoreboard, Paris: OECD publication. Retrieved from: www.oecd.org/sti/scoreboard: 2011

[5] United Nations, International Standard Industrial Classification of All Economic. Series M No. 4/Rev.4. Retrieved from: http://unstats.un.org/unsd/publication/seriesM/seriesm_4rev4e.pdf: 2008

[6] Romo, D. El impacto de la ciencia y la tecnología en el desarrollo de México. Comisión económica para América Latina y el Caribe (CEPAL). Retrieved from: http://www.cepal.org/dmaah/noticias/paginas/1/27731/90946732.pdf: 2012

[7] Romo, A. E., Villalobos, M. A., Guadalupe, L. E.. Gestión del conocimiento: estrategia para la formación de investigadores. Sinéctica, 38. Retrieved from: http://www.sinectica.iteso.mx/index. php?cur=38\&art=38 04: 2012

[8] National Development Plan 2013-2018. Plan Nacional de Desarrollo del Gobierno de la República de México. Retrieved from: http://pnd.gob.mx: 2013

[9] Tobón, S. y Rojas, A. (2013). La gestión del conocimiento desde el pensamiento complejo: un compromiso ético con el desarrollo humano. Revista EAN, (58), 27-40. 
[10] Alles, M. Comportamiento Organizacional: cómo lograr un cambio cultural a través de Gestión por Competencias. Ediciones Granica: 2013.

[11] Gamble, P., Blackwell, J. Knowledge management: A state of the art guide. Kogan Page Publishers: 2001.

[12] Dalkir, K. Knowledge management in theory and practice. Routledge: 2005.

[13] Finkelstein, S., Anderson, P., y Quinn, J. B. La gestión del intelecto profesional: sacar el máximo partido de los mejores. Harvard Deusto Business Review, (75), 4-17: 1996

[14] Montuschi, L. La economía basada en el conocimiento: Importancia del conocimiento tácito y del conocimiento codificado. Documentos de Trabajo 1. Retrieved from: http://www.ucema.edu.ar/publicaciones/download/documentos/204.pdf: 2001

[15] Valencia-Rodríguez, M. Generación y transferencia de conocimiento. Ingeniería Industrial, 34(2), 178-187: 2013

[16] Umunadi, E. Knowledge Management and Global Information Dissemination. Education, 134(3), 395-403: 2014

[17] Alavi, M., y Leidner, D. E. Knowledge management systems: issues, challenges, and benefits. Communications of the AIS, 1(2es), 1: 1999

[18] Alegre, J. y Lapiedra, R. Gestión del conocimiento y desempeño innovador: un estudio del papel mediador del repertorio de competencias distintivas. Cuadernos de Economía y Dirección de la Empresa, (23), 117-138: 2005

[19] Bui, H. y Baruch, Y. Creating learning organization in higher education: applying a systems perspective. Learning Organization, 17 (3), 228-242: 2010.

[20] Figueroa, L. A. El aprendizaje organizacional desde una perspectiva evolutiva y constructivista de la organización. Revista de Psicología, 11(1), Pág-139: 2011

[21] Tapias-García, H. Capacidades tecnológicas: elemento estratégico de la competitividad. Revista Facultad de Ingeniería Universidad de Antioquia, (033), 97-119: 2005.

[22] McClelland, D. C. Does the field of personality have a future? Journal of Research in Personality, 30(3), 429-434: 1996

[23] Alvarez, V., Hechavarria, O., y Sánchez, A. La formación de competencias investigativas profesionales, una mirada desde las ciencias pedagógicas. Cuadernos de Educación y Desarrollo, (24). Retrieved from: http://www.eumed.net/rev/ced/24/vhs.htm: 2011.

[24] Moreno-Bayardo, M. Potenciar la educación. Un currículum transversal de formación para la investigación. REICE-Revista Electrónica Iberoamericana sobre Calidad, Eficacia y Cambio en Educación, 3(1): 2005.

[25] Muñoz, J., Quintero, J. y Munévar, R. Competencias investigativas para profesionales que forman y enseñan: cómo desarrollarlas? COOP. EDITORIAL MAGISTERIO: 2001.

[26] Correa, B. Medición de las competencias investigativas en docentes de fisiología: una aproximación empírica. Rev. Fac. Med.(Bogotá), 57(3), 205-217: 2009

[27] Nuñez Rojas, N. Desarrollo de habilidades para la investigación (DHIN). Universidad Católica Santo Toribio de Mogrovejo, Perú. Revista Iberoaméricana de Educación. 44/6-15: 2007

[28] Izaguirre, R., Baká, P. y Obregón, C. Las competencias para el trabajo científico: una necesidad de la formación profesional. Universidad nacional de Guinea Ecuatorial, facultad de ciencias médicas: 2009.

[29] Molina-Ordóñez, J., Huamaní, C., y Mayta-Tristán, P. Apreciación estudiantil sobre la capacitación universitaria en investigación: estudio preliminar. Rev Peru Med Exp Salud Publica, 25(3), 325-29: 2008.

[30] Fandos, M. El cambio educativo: nuevos escenarios y modalidades de formación. Revista Educar 38, pp. 243 - 258. Retrieved from: http://ddd.uab.cat/pub/educar/0211819Xn38p243.pdf: 2006.

[31] Maldonado, L., Landazábal, D., Hernández, J., Ruíz, Y., Claro, A., Vanegas, H., y Cruz, S. Visibilidad y formación en investigación. Estrategias para el desarrollo de competencias investigativas. Revista Studiositas. Bogotá Colombia. 2 (2): $43-56$. Abril-Junio: 2007.

[32] Barraza, A. La formación docente bajo una conceptualización comprehensiva y un enfoque por competencias. Estudios pedagógicos (Valdivia), 33(2), 131-153: 2007

[33] Rivera Heredia, M. La evaluación de las habilidades de investigación de los estudiantes de Educación Superior: propuesta de un instrumento. Retrieved from: http://www.comie.org.mx/congreso/memoriaelectronica/v09/ponencias/at01/PRE1178867349.pdf: 2009.

[34] Flórez, D., Morales, A., Uribe, C. y Contreras, C. A. Análisis de tendencias en investigación básica para cadenas productivas agroindustriales. Revista Corpoica Ciencia y Tecnología Agropecuaria, 13(2), 121-135: 2012

[35] Ortiz, A. y Arboníes, Á. Conocimiento para innovar. Cómo evitar la miopía en la gestión del conocimiento. Ediciones Díaz de Santos: 2006.

[36] Rodríguez, D. Modelos para la creación y gestión del conocimiento: una aproximación teórica.Revista Educar 37, 2006 25-39. México: 2006

[37] Alvarez, V., Hechavarria, O., y Sánchez, A. La formación de competencias investigativas profesionales, una mirada desde las ciencias pedagógicas. Cuadernos de Educación y Desarrollo, (24). Retrieved from: http://www.eumed.net/rev/ced/24/vhs.htm: 2011.

[38] Prahalad, C. y Hamel, G. The Core Competence of the Corporation. Harvard Business Review, 3, 79-91: 1990

[39] Ramírez Ospina, D. E. Capital intelectual. Algunas reflexiones sobre su importancia en las organizaciones. Revista científica Pensamiento y Gestión, (23): 2011

[40] Acosta-Prado, J., Longo-Somoza, M., y Fischer, A. Capacidades dinámicas y gestión del conocimiento en nuevas empresas de base tecnológica. Cuadernos de Administración, 26(47), 35-62: 2013.

[41] Acosta-Prado, J., y Fischer, A. Condiciones de la gestión del conocimiento, capacidad de innovación y resultados empresariales. Un modelo explicativo. Revista científica Pensamiento y Gestión, (35): 2014.

[42] Delgado-Verde, M., Martín-de Castro, G., Navas-López, J., y Cruz-González, J. (). Capital social, capital intelectual evidencia empírica en sectores e innovación de producto. Manufactureros intensivos en tecnología. INNOVAR. Revista de Ciencias Administrativas y Sociales, 23(50), 93-110: 2011.

[43] Martínez Clares, P., Echeverría Samanes, B. Formación basada en competencias. Revista de investigación educativa,27(1), 125147: 2009.

[44] Bollen, K.A. Structural Equations with Latent Variables. New York: John Wiley \& Sons: 1989.

[45] Mardia, K.V. Measures of multivariate skewers and kurtosis with applications. Biometrika, 36, 519-530: 1970

[46] Arias Martínez, B. Desarrollo de un ejemplo de análisis factorial confirmatorio con LISREL, AMOS y SAS. Publicaciones del INICO, 75: 2008 .

[47] González-Montesinos, M. J., \& Backhoff, E. Validación de un cuestionario de contexto para evaluar sistemas educativos con Modelos de Ecuaciones Estructurales. Relieve, 16(2), 1-17: 2010 
[48] Etzkowitz, H. Innovation in innovation: The triple helix of university, industry-government relations. Social ScienceInformation, 42(3). 367-372: 2003.

[49] Amendola, L., Noguera, S., Depool, T., \& Artacho, M. Á. BLENDED LEARNING COMO RECURSO PARA DESARROLLAR COMPETENCIAS EN DIRECTIVOS INVOLUCRADOS EN UN PROYECTO DE GESTIÓN DE ACTIVOS CON PAS55. XVI Congreso Internacional de Ingeniería de Proyectos Valencia, 11-13 de julio de 2012: 2012.

[50] García Licea, G., Olvera Willes, A., Elizondo, M. M., y López Chavarría, S. Tres Competencias Esenciales de los Profesionales Inteligentes: Advertir y Responder, Combinar y Conectar, y Crear y Producir (Three Essential Skills Smart Professionals: Warn and Answer, Connect and Combine and Create and Produce). Sotavento MBA, (21): 2013.

[51] Weick, K. E., Daft, R. L., en Cameron, K. S., y Whetten, D. A. (Eds.). Organizational effectiveness: A comparison of multiple models. Organizational effectiveness: a comparison of multiple models. New York: Academic Press, 71-93: 1983.

[52] López Cabarcos, A., \& Oliveira Monteiro, S. G. La gestión del conocimiento y el desempeño organizacional: Un estudio aplicado. Economía industrial, (378), 119-125: 2010.

[53] Fundación México Estados Unidos para la Ciencia. Innovación para la competitividad. Reporte anual de actividades 2013. FUMEC: México. Retrieved from: http://fumec.org/v6/htdocs/RepAnual14_Esp.pdf: 2014

[54] Comisión Económica para América Latina y el Caribe. Estadísticas e indicadores de Ciencia, Tecnología e Innovación En América Latina y el Caribe. Documento de apoyo DDA/1 de la Primera reunión de la Conferencia Estadística de las Américas de la Comisión Económica para América Latina y el Caribe. Santiago de Chile, 9 al 11 de mayo de 200. Retrieved from: http://www.cepal.org/deype/publicaciones/xml/9/6769/DDA1e.pdf: 2001.

[55] Lemarchand, G. Sistemas nacionales de ciencia, tecnología e innovación en América Latina y el Caribe. Estudios y documentos de política científica de ALC. Retrieved from: http://disde.minedu.gob.pe/xmlui/handle/123456789/2275: 2010.

[56] Instituto Mexicano de la Propiedad Industrial. (). Sistema de información de la Gaceta de la propiedad intelectual (SIGA). IMPI en cifras 2014. Secretaría de economía de México. Retrieved from http://www.impi.gob.mx/: 2014.

[57] Organización Mundial de la Propiedad Intelectual. Indicadores Mundiales de Propiedad Intelectual edición 2013. world intellectual property indicators. WIPO. Retrieved from: http://www.wipo.int/ipstats/en/wipi/: 2013.

[58] Garvin, D., Edmondson, A. y Gino, F. Is yours a learning organization? Harvard business review, 86(3), 109: 2008

[59] Boam, R. y Sparrow, P. Designing and Achieving Competency: A Competency-based Approach to Developing People and Organisations, McGraw-Hill, London: 1992.

[60] Edvinsson, L. y Sullivan, P. Developing a model for managing intellectual capital. European management journal, 14(4), 356-364: 1996

[61] Lev, B. Intangibles: Management, measurement, and reporting. Brookings Institution Press: 2000.

[62] Nevado, D., y López, V. R. El capital intelectual: valoración y medición. Editorial: Prentice Hall, España: 2002.

[63] Garvin, D. Building a learning organization. Harvard Business Review, 78-91: 1998

[64] Gamble, P. R., \& Blackwell, J. Knowledge management: A state of the art guide. Kogan Page Publishers: 2001.

[65] Prahalad, C. y Hamel, G. The Core Competence of the Corporation. Harvard Business Review, 3, 79-91: 1990.

[66] Bontis, N. Intellectual capital: an exploratory study that develops measures and models. Management decision, 36(2), 63-76: 1998.

[67] Bradley, K. Intellectual capital and the new wealth of nations. Business Strategy Review, 8(1), 53-62: 1997.

[68] Dierickx, I., y Cool, K. Asset stock accumulation and sustainability of competitive advantage. Management science, 35(12), 15041511: 1989.

[69] Roos, G., Bainbridge, A. y Jacobsen, K. Intellectual capital analysis as a strategic tool. Strategy \& Leadership, 29(4), 21-26: 2001.

[70] Von Krogh G., y Roos, J. A perspective on knowledge, competence and strategy. Personnel Review, Vol. 24 Iss: 3 , pp.56 - 76: 1995

[71] Winter, S. Knowledge and competence as strategic assets. The strategic management of intellectual capital, 165-187: 1998. 